Jurnal Penelitian Hutan Tanaman Vol. 15 No. 1, Juni 2018, 1-66

ISSN: 1829-6327, E-ISSN: 2442-8930

Terakreditasi No: 677/AU3/P2MI-LIPI/07/2015

\title{
PERBANYAKAN VEGETATIF MAHONI (Swietenia macrophylla King) DENGAN CARA STEK PUCUK
}

\author{
Vegetative Propagation of Mahogany (Swietenia macrophylla King) by Cuttings \\ Hani Sitti Nuroniah, Yeni Nuraeni dan/and Rina Bogidarmanti \\ Pusat Penelitian dan Pengembangan Hutan \\ Jl. Gunung Batu No. 5, Bogor, Jawa Barat, Indonesia. Telp. (0251) 8633234, 7520067; Fax. (0251) 8638111 \\ Email: nuroniah@yahoo.com; y.nuraeni999@gmail.com; rinabogidarmanti@yahoo.com
}

Tanggal diterima: 5 Mei 2017; Tanggal direvisi: 26 April 2018; Tanggal disetujui: 31 Mei 2018

\begin{abstract}
Mahogany (Swietenia macrophylla) plantations are threatened by shoot borer (Hypsiyla robusta), therefore the resistance of mahogany plants to shoot borer become a priority for the establishment of mahogany plantations. Elite trees that have resistance to shoot borer could be found through genetic selection of mahogany population in the field. Propagation of these elite trees should be prepared by vegetative propation to ensure that the mother plant's characteristics were inherited. Vegetative propagation of mahogany was conducted by cuttings. The experiment design consisted of split plot in randomly group with 4 medias and 3 IBA treatments; repeated 3 groups with 15 seedlings per experimental unit. Cutting materials were collected from one year old seedlings. Successful cutting was determined by these parameters: percentage of rooted cuttings, numbers of root, root length, shoot length, root biomass, and shoot biomass. The results showed that media factor had significant effect to cuttings, while soaking cutting material in growth regulators gave no significant effect. The highest percentage of rooted cutting was produced by media cocopeat + husk $(2: 1, v / v)$ by $93 \%$. The greatest number of roots were generated using rice husk and coconut + husk $(2: 1, v / v)$ by 4.5 strands of roots. The longest root was produced using media soil by length $86 \mathrm{~mm}$. Based on these cutting parameters, cocopeat + husk is the most optimal media for mahogany cuttings.
\end{abstract}

Keywords: cuttings, mahogany, rooting media

\begin{abstract}
ABSTRAK
Penanaman mahoni terancam oleh serangan hama penggerek pucuk Hypsipyla robusta, sehingga pencarian mahoni yang memiliki sifat resisten menjadi prioritas dalam pengembangan mahoni. Seleksi genetik dari populasi mahoni di lapangan yang terbukti memiliki ketahanan terhadap Hypsipila adalah salah satu cara untuk memperoleh pohon unggul mahoni. Perbanyakan bibit dari pohon unggul harus dilakukan secara vegetatif agar anakan memperoleh sifat unggul dari induknya. Pada penelitian ini, perbanyakan vegetatif pada spesies mahoni (Swietenia macrophylla) telah dilakukan dengan cara stek pucuk. Rancangan penelitian menggunakan split plot dalam rancangan acak kelompok dengan petak utama jenis media yang terdiri atas 4 jenis media, anak petak konsentrasi zat pengatur tumbuh yaitu 3 konsentrasi IBA, dan dikelompokan menjadi 3 kelompok. Bahan stek diambil dari pucuk anakan umur 1 tahun. Keberhasilan stek pucuk dilihat dari parameter persentase berakar, jumlah akar, panjang akar, panjang tunas, biomassa akar, dan biomassa pucuk. Faktor media berpengaruh nyata terhadap proses stek, sedangkan pemberian IBA dengan cara perendaman basal tidak memberikan pengaruh nyata. Persentase berakar tertinggi dihasilkan dari media campuran sabut kelapa+sekam $(2: 1, \mathrm{v} / \mathrm{v})$ sebesar $93 \%$ atau lebih tinggi 16\% dibandingkan media kontrol (tanah). Jumlah akar terbanyak dihasilkan dari media arang sekam dan campuran sabut kelapa+sekam $(2: 1, \mathrm{v} / \mathrm{v})$ sebanyak 4,5 helai atau naik sebesar $47 \%$ dibandingkan kontrol. Panjang akar tertinggi dihasilkan oleh kontrol (media tanah) dengan nilai $86 \mathrm{~mm}$. Berdasarkan parameter pertumbuhan stek, media sabut kelapa+sekam $(2 ; 1, \mathrm{v} / \mathrm{v})$ merupakan media yang paling optimal untuk stek pucuk mahoni.
\end{abstract}

Kata kunci: mahoni, media perakaran, stek pucuk 


\section{PENDAhuluan}

\section{A. Latar Belakang}

Mahoni (Swietenia macrophylla King) termasuk famili Meliaceae dan dikenal sebagai jenis penghasil kayu bernilai ekonomi tinggi yang digolongkan sebagai kayu mewah. Jenis tanaman ini termasuk intoleran, yaitu jenis pohon pada saat tingkat permudaan tidak membutuhkan naungan. Oleh karena itu, mahoni potensial dikembangkan di hutan tanaman (Hutan Tanaman Industri dan Hutan Rakyat) dan untuk kegiatan rehabilitasi hutan dan lahan.

Penanaman mahoni terancam oleh serangan terus-menerus dari hama penggerek pucuk Hypsipila robusta (Opunifrimpong, Karnosky, Storer, Abeney, \& Cobbinah, 2008) yang menghancurkan meristem apikal dan menyebabkan banyak percabangan (multi shoots), sehingga mengurangi nilai ekonomi kayunya. Karena itu, pencarian mahoni yang memiliki sifat resisten menjadi prioritas dalam pengembangan mahoni. Pencarian pohon mahoni dari populasi di lapangan yang terbukti memiliki ketahanan terhadap Hypsipila adalah salah satu cara untuk memperoleh klona unggul mahoni.

Perolehan klona unggul memerlukan teknik perbanyakan vegetatif agar diperoleh bibit yang memiliki karakteristik sama dengan induknya, misalnya pertumbuhan yang bagus, atau memiliki sifat toleran terhadap serangan hama dan penyakit. Hal ini mengingat anakan hasil vegetatif dipastikan akan memperoleh sifat unggul yang sama dengan induknya, sedangkan perbanyakan sistem generatif belum tentu akan mewariskan semua sifat unggulnya. Sistem stek pucuk merupakan salah satu cara perbanyakan vegetatif yang efisien dan berbiaya murah. Berbagai jenis Meliaceae telah sukses diperbanyak dengan cara stek, contohnya Khaya anthotheca, K. ivorensis, $K$. senegalensis, Entandrophragma angolense, dan E. utile (Barbosa Filho et al., 2016; de Vasconcelos, Valeri, Martins, Biagiotti, \& Perez, 2016; Owusu, Opuni-Frimpong, \& Antwi-Boasiako, 2014; Ky-Dembele et al., 2011; Opuku, Opuni-Frimpong, \& Adomako, 2008)

Keberhasilan stek dipengaruhi oleh faktor internal (tanaman) dan eksternal (lingkungan). Faktor bahan tanaman ditentukan oleh karakter genetik, kandungan cadangan makanan, ketersediaan air, hormon endogen, tingkat juvenil dan umur tanaman. Faktor lingkungan ditentukan oleh media perakaran, kelembaban, suhu, intensitas cahaya, dan teknik penyetekan serta perlakuan stek, seperti zat pengatur tumbuh dan luas area daun (Rupp \& Wheaton, 2014).

Penelitian ini bertujuan mencari jenis media dan konsentrasi hormon yang optimal untuk perbanyakan mahoni dengan cara stek pucuk. Peningkatan persentase keberhasilan perakaran dengan mengoptimalkan kedua faktor di atas akan berpengaruh terhadap kelayakan ekonomi saat spesies akan diperbanyak secara komersial.

\section{METODOLOGI}

\section{A. Waktu dan Lokasi Penelitian}

Penelitian ini dilaksanakan dari bulan September 2016 sampai Desember 2016. Lokasi penelitian di rumah kaca yang dilengkapi fasilitas pengkabutan sistem Koffco (Sakai, Subiakto, Nuroniah, Kamata, \& Nakamura, 2002), Laboratorium Silvikultur Pusat Penelitian dan Pengembangan Hutan, Bogor. 


\section{B. Metode \\ 1. Prosedur kerja}

Media perakaran (pasir, tanah, dan sabut kelapa + sekam), kecuali arang sekam terlebih dahulu, sterilisasi dengan metode penguapan. Media perakaran dimasukkan ke dalam pottray, selanjutnya bahan stek ditanam pada media. Bahan stek adalah anakan (seedling) mahoni umur 1 tahun. Bahan stek dipotong dengan ukuran minimal tiga ruas daun dengan menyisakan dua helai daun teratas (Irawan, \& Purwanto, 2012; Sakai et al., 2002). Daun yang tersisa dipotong separuhnya kemudian bagian basal bahan stek direndam dalam larutan sesuai dengan perlakuan konsentrasi hormon tumbuh IBA (Indol-3butyric acid) selama 30 menit. Pottray yang telah berisi stek dimasukkan ke dalam sungkup transparan. Proses stek dilakukan di rumah kaca yang dilengkapi sistem pengkabutan selama 3 bulan. Selama proses stek, kelembaban dalam sungkup dijaga dengan penyiraman secara berkala. Pada umur 3 bulan setelah penanaman dilakukan pengamatan keberhasilan stek dengan menghitung persentase stek berakar, jumlah akar, panjang akar, panjang tunas, biomassa akar, dan biomassa tunas.

\section{Analisis media stek mahoni}

Sifat fisik media yang diukur meliputi kerapatan lindak (bulk density), ruang pori total, kadar air, pori drainase, air tersedia, dan permeabilitas. Pengujian dilakukan di Laboratorium Tanah BIOTROP.

\section{Rancangan percobaan}

Rancangan percobaan yang digunakan dalam penelitian ini yaitu Rancangan Split Plot dalam rancangan acak kelompok yang dikelompokan menajdi tiga kelompok dengan masing-masing unit amatan terdiri atas lima belas stek. Petak utama adalah media yang terdiri atas empat jenis media yaitu pasir, tanah, sabut kelapa+sekam $(2: 1, \mathrm{v}: \mathrm{v})$, dan arang sekam. Anak petak berupa zat pengatur tumbuh IBA, yaitu dosis 0 ppm, 100 ppm, dan 200 ppm.

\section{Analisis data}

Analisis data dilakukan untuk mengetahui pengaruh perlakuan terhadap parameter yang diamati dengan uji Analisys of Variance (ANOVA). Selanjutnya, uji Duncan dilakukan apabila hasil analisis berbeda nyata.

\section{HASIL DAN PEMBAHASAN}

\section{A. Hasil}

Hasil analisis sidik ragam (Tabel 1) menunjukkan bahwa faktor media stek berpengaruh sangat nyata terhadap panjang akar, persentase berakar, dan jumlah akar, sedangkan terhadap biomassa akar dan biomassa tunas tidak berpengaruh nyata. Faktor zat pengatur tumbuh (IBA) hanya berpengaruh nyata pada panjang akar saja, tetapi tidak berpengaruh nyata terhadap persentase berakar, jumlah akar, panjang tunas, biomassa akar, dan biomassa tunas. Interaksi antara faktor media dan zat pengatur tumbuh tidak berpengaruh nyata terhadap parameter yang diamati.

Hasil uji lanjut pengaruh media tanam terhadap persentase stek berakar, jumlah akar, dan panjang tunas menunjukkan bahwa media terbaik untuk stek mahoni adalah campuran sabut kelapa+sekam padi $(2: 1, \mathrm{v} / \mathrm{v})$, yang telah menghasilkan nilai persentase stek berakar sebesar 93\% dan jumlah akar sebanyak 4,5 helai (Tabel 2).

Media berpengaruh nyata terhadap persentase berakar, jumlah akar, dan panjang akar (Tabel 2). Pemberian IBA dengan dosis 100 ppm dan 200 ppm hanya 
memberikan respons berbeda nyata terhadap panjang akar saja (Tabel 3). Media yang digunakan ataupun dosis IBA tidak berpengaruh terhadap biomassa akar ataupun biomassa tunas.

Berdasarkan hasil analisis media, tanah memiliki nilai kerapatan lindak paling tinggi. Arang sekam memiliki nilai tertinggi untuk ruang pori total, kadar air, pori drainase pada saat lambat, air tersedia, dan permeabilitas bila dibandingkan dengan media sabut kelapa+sekam (2:1, v/v), pasir, dan tanah (Tabel 4).

Tabel (Table) 1. Rekapitulasi $F$-hitung pengaruh media dan IBA terhadap stek mahoni (Recapitulation of F-count on effect of media and IBA on mahoni cuttings)

\begin{tabular}{|c|c|c|c|c|c|c|}
\hline $\begin{array}{l}\text { Sumber } \\
\text { keragaman } \\
\text { (Source) }\end{array}$ & $\begin{array}{l}\text { Persentase berakar } \\
\text { (Rooted cuttings } \\
\text { percentage) }\end{array}$ & $\begin{array}{c}\text { Jumlah akar } \\
\text { (Numbers of } \\
\text { root) }\end{array}$ & $\begin{array}{l}\text { Panjang } \\
\text { akar } \\
\text { (Root } \\
\text { length) }\end{array}$ & $\begin{array}{l}\text { Panjang } \\
\text { tunas } \\
\text { (Shoot } \\
\text { length) }\end{array}$ & $\begin{array}{l}\text { Biomassa } \\
\text { akar } \\
\text { (Root } \\
\text { biomass) }\end{array}$ & $\begin{array}{l}\text { Biomassa } \\
\text { tunas } \\
\text { (Shoot } \\
\text { biomass) }\end{array}$ \\
\hline Media (Media) & $4.252 *$ & $4.265^{*}$ & $18.520 * *$ & $11.231 * *$ & $1.396^{\text {tn }}$ & $0.895^{\mathrm{tn}}$ \\
\hline IBA & $2.154^{\mathrm{tn}}$ & $2.085^{\mathrm{tn}}$ & $4.418 *$ & $0.192^{\text {tn }}$ & $2.834^{\mathrm{tn}}$ & $2.100^{\mathrm{tn}}$ \\
\hline Interaksi & $0.923^{\mathrm{tn}}$ & $0.553^{\mathrm{tn}}$ & $1.239^{\mathrm{tn}}$ & $0.966^{\mathrm{tn}}$ & $1.028^{\mathrm{tn}}$ & $0.834^{\mathrm{tn}}$ \\
\hline
\end{tabular}

Tabel (Table) 2. Uji beda pengaruh media terhadap stek mahoni (Analysis of variance on effect of media on mahoni cuttings)

\begin{tabular}{|c|c|c|c|c|c|c|}
\hline $\begin{array}{l}\text { Media } \\
\text { (Media) }\end{array}$ & $\begin{array}{l}\text { Persentase } \\
\text { berakar }(\%) \\
\text { (Rooted } \\
\text { cuttings } \\
\text { percentage) }\end{array}$ & $\begin{array}{l}\text { Jumlah } \\
\text { akar } \\
\text { (helai) } \\
\text { (Numbers } \\
\text { of root) } \\
\end{array}$ & $\begin{array}{c}\text { Panjang } \\
\text { akar (mm) } \\
\text { (Root } \\
\text { length) }\end{array}$ & $\begin{array}{l}\text { Panjang } \\
\text { tunas } \\
(\mathrm{mm}) \\
\text { (Shoot } \\
\text { length) }\end{array}$ & $\begin{array}{l}\text { Biomassa } \\
\text { akar }(\mathrm{g}) \\
\text { (Root } \\
\text { biomass) }\end{array}$ & $\begin{array}{l}\text { Biomassa } \\
\text { tunas }(\mathrm{g}) \\
\text { (Shoot } \\
\text { biomass) }\end{array}$ \\
\hline $\begin{array}{l}\text { Arang sekam (Rice husk } \\
\text { charcoal) }\end{array}$ & $80.741^{\mathrm{ab}}$ & $4.444^{\mathrm{a}}$ & $64.007^{b}$ & $31.978^{\mathrm{a}}$ & $3.866^{\mathrm{a}}$ & $1.960^{\mathrm{a}}$ \\
\hline $\begin{array}{l}\text { Tanah (soil) } \\
\text { Sabut kelapa+ sekam } \\
\text { (Cocopeat + rice husk) }(2: 1 \text {, } \\
\text { v/v) }\end{array}$ & $\begin{array}{l}80.741^{\mathrm{ab}} \\
93.333^{\mathrm{a}}\end{array}$ & $\begin{array}{l}3.111^{\mathrm{b}} \\
4.556^{\mathrm{a}}\end{array}$ & $\begin{array}{l}85.926^{\mathrm{a}} \\
36.179^{\mathrm{c}}\end{array}$ & $\begin{array}{l}29.311^{\mathrm{a}} \\
28.022^{\mathrm{a}}\end{array}$ & $\begin{array}{l}2.796^{\mathrm{a}} \\
2.449^{\mathrm{a}}\end{array}$ & $\begin{array}{l}2.442^{\mathrm{a}} \\
1.611^{\mathrm{a}}\end{array}$ \\
\hline Pasir (Sand) & $74.074^{\mathrm{b}}$ & $3.778^{\mathrm{ab}}$ & $57.878^{\mathrm{b}}$ & $20.333^{\mathrm{b}}$ & $2.629^{\mathrm{a}}$ & $2.176^{\mathrm{a}}$ \\
\hline
\end{tabular}


Tabel (Table) 3. Uji beda pengaruh IBA terhadap stek mahoni (Analysis of variance on effect of IBA on mahoni cuttings)

\begin{tabular}{lcccccc}
\hline $\begin{array}{l}\text { IBA } \\
(\mathrm{ppm})\end{array}$ & $\begin{array}{c}\text { Persentase berakar } \\
(\%) \\
\begin{array}{c}\text { Rooted cuttings } \\
\text { percentage })\end{array}\end{array}$ & $\begin{array}{c}\text { Jumlah akar } \\
(\text { helai) } \\
\left(\begin{array}{c}\text { Numbers of } \\
\text { root) }\end{array}\right.\end{array}$ & $\begin{array}{c}\text { Panjang akar } \\
(\mathrm{mm}) \\
(\text { Root length) }\end{array}$ & $\begin{array}{c}\text { Panjang tunas } \\
(\mathrm{mm}) \\
\text { (Shoot length) }\end{array}$ & $\begin{array}{c}\text { Biomassa } \\
\text { akar }(\mathrm{g}) \\
(\text { Root } \\
\text { biomass) }\end{array}$ & $\begin{array}{c}\text { Biomassa } \\
\text { tunas }(\mathrm{g}) \\
(\text { Shoot } \\
\text { biomass })\end{array}$ \\
\hline 0 & $80,00^{\mathrm{a}}$ & $4,33^{\mathrm{a}}$ & $59,64^{\mathrm{ab}}$ & $26,90^{\mathrm{a}}$ & $3,20^{\mathrm{a}}$ & $1,95^{\mathrm{a}}$ \\
100 & $85,56^{\mathrm{a}}$ & $3,67^{\mathrm{a}}$ & $54,64^{\mathrm{b}}$ & $27,10^{\mathrm{a}}$ & $2,57^{\mathrm{a}}$ & $1,72^{\mathrm{a}}$ \\
200 & $81,11^{\mathrm{a}}$ & $3,93^{\mathrm{a}}$ & $68,71^{\mathrm{a}}$ & $28,23^{\mathrm{a}}$ & $3,04^{\mathrm{a}}$ & $2,46^{\mathrm{a}}$ \\
\hline
\end{tabular}

Keterangan (Remark): Angka pada kolom yang sama yang diikuti oleh huruf yang sama tidak berbeda nyata pada taraf uji 5\% (Values in same colomn followed by the same letter are not significantly different at level 5\%)

Tabel (Table) 4. Sifat fisik media perakaran (The physical characteristics of rooting media)

\begin{tabular}{|c|c|c|c|c|}
\hline & $\begin{array}{c}\text { Sabut kelapa } \\
\text { +sekam } \\
\text { (Cocopeat }+ \text { husk }) \\
(2: 1, \mathrm{v} / \mathrm{v}) \\
\end{array}$ & $\begin{array}{c}\text { Arang } \\
\text { Sekam } \\
\text { (Husk } \\
\text { charcoal) } \\
\end{array}$ & $\begin{array}{l}\text { Pasir } \\
\text { (Sand) }\end{array}$ & $\begin{array}{r}\text { Tanah } \\
(\text { Soil })\end{array}$ \\
\hline Kerapatan lindak (Bulk density) (gr/cc) & $0,76^{*}$ & 0,41 & $1,19 *$ & 1,28 \\
\hline Ruang pori total (Porisity) (\%) & $53,94 *$ & 75,15 & $55,09^{*}$ & 51,70 \\
\hline $\begin{array}{l}\text { Kadar air pada (Moisture content at): } \\
\text { - Pori drainase cepat (Fast drainage pore) } \\
\text { Pf } 1 \%\end{array}$ & $53,56^{*}$ & 75,01 & $52,64 *$ & 50,18 \\
\hline - Pori drainase (Drainage pore) Pf $2 \%$ & $53,10^{*}$ & 74,79 & $48,38^{*}$ & 49,01 \\
\hline $\begin{array}{l}\text { - Kapasitas lapang (Field capacity) Pf } \\
2,54 \%\end{array}$ & $45,95^{*}$ & 66,58 & $47,26^{*}$ & 45,37 \\
\hline $\begin{array}{l}\text { - Titik layu permanen (Permanent wilting } \\
\text { point) Pf } 4,20 \%\end{array}$ & $24,30 *$ & 36,22 & $38,71 *$ & 32,18 \\
\hline \multicolumn{5}{|l|}{ Pori drainase (Drainage pore) } \\
\hline - Cepat $($ Fast $)(\%)$ & $0,84^{*}$ & 0,36 & $6,71^{*}$ & 2,69 \\
\hline - $\quad$ Lambat (Slow) $(\%)$ & 7,15 & 8,21 & 1,12 & 3,64 \\
\hline Air tersedia (Available water capacity) $(\%)$ & $21,65^{*}$ & 30,36 & $8,55^{*}$ & 13,19 \\
\hline Permeabilitas (Permeability) $\mathrm{cm} / \mathrm{jam}(\mathrm{cm} /$ hour $)$ & 52,36 & 67,08 & 36,27 & 6,46 \\
\hline
\end{tabular}

Keterangan (Remark): *Sumber data dari Darwo \& Yeny (2018) (Data source from Darwo \& Yeny (2018))

Media memiliki empat fungsi dalam proses stek, yaitu menjadi tempat tumbuh, menjaga kelembaban, memudahkan pertukaran udara, dan menyediakan kondisi gelap untuk proses perakaran. Sifat fisik media merupakan faktor yang berpengaruh nyata terhadap kesuksesan proses stek (Danu, \& Putri, 2014; Vlad, Mariana, \& Ioana, 2012; Mariana, Ioan, \& Ioana, 2011; Andra, Vlad, Vlad, \& Vlad, 2010;
Opuku et al., 2008). Pada percobaan ini, tanah dianggap sebagai kontrol karena tanah merupakan media yang paling mudah diperoleh dan dipergunakan untuk kegiatan perbanyakan vegetatif, baik untuk stek maupun cangkok. Hasil penelitian ini menunjukkan bahwa sabut kelapa+sekam $(2: 1, \mathrm{v} / \mathrm{v})$ merupakan media yang paling optimal untuk stek mahoni karena menghasilkan nilai tertinggi bagi tiga parameter, 
yaitu persentase berakar, jumlah akar, dan panjang tunas dibandingkan dengan ketiga media lainnya. Dibandingkan dengan kontrol, media sabut kelapa+sekam (2:1, v/v) memiliki peningkatan sebesar $16 \%$ untuk kemampuan berakar dan $47 \%$ untuk jumlah akar, namun berkurang $1 \%$ untuk panjang tunas.

Media perakaran stek lebih memerlukan porositas yang yang baik yang memungkinkan terjadinya aliran udara dan aliran air serta ketersediaan air yang cukup (Danu, \& Putri, 2014; Zhao et al., 2014). Porositas media dapat diketahui antara lain dari kerapatan lindak. Semakin rendah kerapatan lindak, semakin mudah media meneruskan air atau ditembus akar. Kerapatan lindak juga berkaitan dengan kemampuan media dalam menyerap air (porositas media). Semakin kecil porositas media, maka semakin mudah media menyerap dan menyimpan air sehingga memudahkan akar untuk menembus media (Hanafiah, 2010).

Media sabut kelapa+sekam $(2: 1, \mathrm{v} / \mathrm{v})$ cenderung bersifat tidak padat, namun porositasnya lebih tinggi dibandingkan dengan media lainnya. Sabut kelapa+ sekam $(2: 1, \mathrm{v} / \mathrm{v})$ memiliki kerapatan lindak rendah, jumlah air tersedia yang besar, kapasitas lapang dan titik layu permanennya rendah. Titik layu permanen merupakan nilai lengas tanah pada keadaan tanaman mulai layu. Pada kondisi nilai lengas di bawah titik layu permanen, air tidak dapat diserap oleh akar tanaman dengan cepat, sehingga tidak mampu mengimbangi laju transpirasi (Hanafiah, 2010).

Tiga media lainnya juga dapat digunakan sebagai media stek mahoni karena menghasilkan persentase berakar antara $74-80 \%$. Pasir sering dipergunakan sebagai media perakaran karena murah, banyak tersedia, dan bersih. Namun, terdapat sifat kelemahan pasir sebagai media karena permeabilitasnya tinggi dan jumlah air tersedia pun rendah. Kemampuan menyimpan air yang rendah menyebabkan pasir memerlukan frekuensi penyiraman yang lebih tinggi. Sementara itu, arang sekam memiliki kapasitas air tersedia yang tinggi, namun cepat pula kehilangan air karena permeabilitasnya tinggi, sehingga frekuensi penyiraman juga harus tinggi.

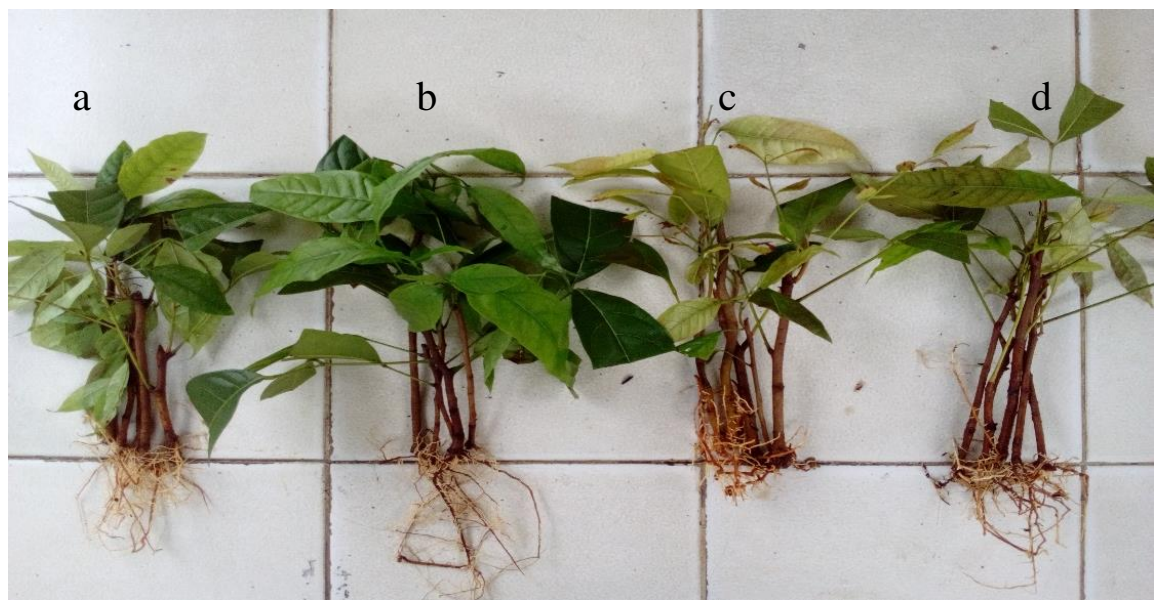

Gambar (Figure) 1. Performa stek mahoni setelah 3 bulan proses perakaran pada empat media uji: a. tanah, b. pasir, c. cocopeat+sekam d. arang sekam (Performance of mahogany cuttings after 3 months of rooting process on four tested media: a. soil, b. Sand, c. cocopeat+rice husk, d. rice husk charcoal). 
Hormon terpenting selama proses stek adalah auksin dan sitokinin. Transportasi auksin dan sinyal dari auksin mengontol pertumbuhan dan perkembangan tanaman. Contoh hormon auksin antara lain Indole Acetic Acid (IAA) dan IBA. Hormon IBA diketahui lebih efektif dari IAA karena 1) lebih stabil dan dapat berubah menjadi IAA melalui mekanisme seperti fatty acid $\beta$-oxidation, 2) IBA juga dapat menstimulasi transportasi IAA ke bagian bawah tanaman, dan 3) IBA eksogen dapat dipindah ke basal dan bertransformasi menjadi IAA (Zhao et al., 2014).

Pada penelitian ini, penambahan IBA tidak memberikan pengaruh yang berbeda nyata terhadap persentase berakar pada stek mahoni. Pada beberapa jenis tanaman, proses pembentukan akar dapat terjadi secara alami tanpa penambahan hormon auksin dari luar. Munculnya akar stek tanpa penambahan auksin juga ditunjukkan dari hasil percobaan stek terhadap jenis dari famili Meliaceae lainnya, antara lain mahoni Afrika (Khaya anthotheca dan K. Ivorensis) (Opuni-Frimpong, Karnosky, Storer, \& Cobbinah, 2008) dan K. senegalensis (de Vasconcelos et al., 2016).

Level auksin, tingkat homeostatik, dan ketersediaan karbohidrat di bagian basal stek berpengaruh signifikan selama tahap awal pembentukan akar adventif (OuYang, Wang, \& Li, 2015, AgullóAntón et al, 2014;). Menurut Agulló-Antón et al. (2014), auksin dari luar tidak memengaruhi level auksin endogen selama proses perakaran. Inisiasi pembentukan akar terjadi selama jam pertama setelah pemotongan akibat adanya pelukaan yang memutuskan jalur transportasi dan menyebabkan auksin berkumpul di area pelukaan, namun stimulus ini tidak dipengaruhi auksin luar. Selanjutnya, auksin endogen akan mengalami penurunan, dan berada dalam konsentrasi stabil, serta konsentrasinya tidak dipengaruhi oleh auksin eksogen selama terjadinya proses pembentukan akar (Stuepp, Wendling, Trueman, Koehler, \& Zuffellato-Ribas, 2017; Agulló-Antón et al., 2014).

Tingginya hormon auksin endogen disebabkan oleh penggunaan bahan stek juvenil yang sudah cukup untuk menginduksi terbentuknya akar (de Souza et al., 2014). Materi stek yang digunakan pada penelitian ini berupa anakan berumur satu tahun yang masih memiliki sifat juvenil, sehingga kandungan karbohidrat dan hormon auksin yang terkandung dalam jaringan masih tinggi (de Souza et al., 2014; Zhao et al., 2014). Hasil penelitian Danu, Siregar, Wibowo, \& Subiakto (2010) menyatakan bahwa stek muda memiliki kandungan $\mathrm{C}, \mathrm{N}, \mathrm{P}$, dan rasio $\mathrm{C} / \mathrm{N}$ yang tinggi. Cadangan karbohidrat yang tinggi mendukung pertumbuhan tunas dan daun baru. Tunas mampu menghasilkan hormon auksin dan mentransfernya ke bawah untuk menstimulasi pembentukan akar (Zhao et al., 2014). Hal ini sesuai pendapat Danu, Putri, \& Subiakto (2015) yang membuktikan adanya korelasi antara kandungan karbohidrat yang tinggi terhadap keberhasilan perakaran pada stek jabon merah. Selain itu, sifat juvenil dari bahan stek terbukti mendukung terjadinya perakaran (Majada et al., 2011) namun sumber stek dari pohon dewasa dan batang lainnya diperlukan untuk memperluas sumber stek (Jong, \& Sani, 2012).

\section{KESIMPULAN DAN SARAN}

\section{A. Kesimpulan}

Sabut kelapa+sekam (2:1, v/v) merupakan media yang paling optimal untuk stek mahoni dengan persentase berakar mencapai 93\%. Sumber stek dari 
tanaman yang masih muda dapat diperbanyak dengan cara stek tanpa memerlukan penambahan zat pengatur tumbuh.

\section{B. Saran}

Perbanyakan mahoni dengan cara stek dapat dilakukan menggunakan media sabut kelapa+sekam $(2: 1, \quad \mathrm{v} / \mathrm{v})$ tanpa penambahan zat pengatur tumbuh. Untuk mengetahui kemampuan perbanyakan vegetatif mahoni secara utuh, penelitian menggunakan materi bahan stek yang berasal dari pohon tua sebaiknya dilakukan pula.

\section{UCAPAN TERIMA KASIH}

Penelitian ini dibiayai dari DIPA APBN Pusat Litbang Hutan tahun 2016. Penulis mengucapkan terima kasih kepada Ir. Atok Subiakto, MSc yang telah mengizinkan penggunaan fasilitas persemaian dan rumah kaca yang dilengkapi fasilitas pengkabutan sistem Koffco. Penulis juga mengucapkan terima kasih kepada Wahyu, Nasir, dan Marni yang telah membantu kegiatan penelitian ini.

\section{DAFTAR PUSTAKA}

Agulló-Antón, M.Á., Ferrández-Ayela, A., Fernández-García, N., Nicolás, C., Albacete, A., Pérez-Alfocea, F., ... Acosta, M. (2014). Early steps of adventitious rooting: Morphology, hormonal profiling and carbohydrate turnover in carnation stem cuttings. Physiologia Plantarum, 150(3), 446462. http://doi.org/10.1111/ppl.12114

Andra, V. I., Vlad, I., Vlad, M., \& Vlad, R. (2010). Research regarding the content of dry substance and mineral elements of the leaves of Thuja occidentalis under the influence of the culture system and of the fertilization conditions. Analele Universitatii Din Oradea, XV, 323-326.

Barbosa Filho, J., Di Carvalho, M.A., Silva de Oliveira, L., Konzen, E.R., Ferreria Campos, W., \& Ebling Brondani, G. (2016). Propagation of Khaya Anthotheca: Interspecific Grafting With Swietenia macrophylla and Air Layering. Cerne, 22(4), 475-484. http://doi.org/10.1590/0104776020162 2042232

Danu, \& Putri, K.P. (2014). Pengaruh sifat fisik media dan zat pengatur tumbuh IBA pada pertumbuhan stek kayu bawang (Azadirachta excelca L.). Jurnal Perbenihan Tanaman Hutan, 2 (2), 89-98.

Danu, Putri, K.P., \& Subiakto, A. (2015). Pertumbuhan stek jabon merah (Anthocephalus macrophyllus [Roxb.] Havil) pada berbagai media dan zat pengatur tumbuh. Jurnal Penelitian Hutan Tanaman, 12 (2), 123-130.

Danu, Siregar, I.Z., Wibowo, C., \& Subiakto, A. (2010). Pengaruh umur sumber bahan stek terhadap keberhasilan stek pucuk meranti tembaga (Shorea leprosula Miq.). Jurnal Penelitian Hutan Tanaman, 7 (3), 131-139.

Darwo \& Yeny, I. (2018). Penggunaan media, bahan stek, dan zat pengatur tumbuh terhadap keberhasilan stek masoyi (Cryptocarya massoy (Oken) Kosterm). Jurnal Penelitian Hutan Tanaman (Belum terbit)

de Souza, J.C.A.V., Bender, A.G., Tivano, J.C., Barroso, D.G., Mroginski, L.A., Vegetti, A.C., \& Felker, P. (2014). Rooting of Prosopis alba minicuttings. New Forests, 45(5), 745-752. 
http://doi.org/10.1007/s11056-0149429-5

de Vasconcelos, R.T., Valeri, S.V, Martins, A.B.G., Biagiotti, G., \& Perez, B.A. P. (2016). Rooting of African mahogany (Khaya senegalensis A. Juss.) leafy stem cuttings under different concentrations of indole-3-butyric acid. African Journal of Agricultural Research, 11(23), 2050-2057. http://doi.org/10.5897/AJAR2016.109 36

Hanafiah, K.A. (2010). Dasar-Dasar Ilmu Tanah. Jakarta: Rajawali Pers.

Harfouche, A., Baoune, N., \& Merazga, H. (2007). Main and interaction effects of factors on softwood cutting of white poplar (Populus alba L.). Silvae Genetica, 56, 287-294.

Irawan, U.S., \& Purwanto, E. (2012). Manual: Teknik Pembibitan Vegetatif. Indonesia: Operation Wallacea Trust.

Jong, L.K., \& Sani, H.B. (2012). Alternative clonal propagation of Dryobalanops baccarii and D. rappa. Journal of Tropical Forest Science, 24(2), 275-284.

Ky-Dembele, C., Tigabu, M., Bayala, J., Savadogo, P., Boussim, I.J., \& Odén, P.C. (2011). Clonal Propagation of Khaya senegalensis: The Effects of Stem Length, Leaf Area, Auxins, Smoke Solution, and Stockplant Age. International Journal of Forestry Research, 2011, 1-10. http://doi.org/10.1155/2011/281269

Majada, J., Martínez-Alonso, C., Feito, I., Kidelman, A., Aranda, I., \& Alía, R. (2011). Mini-cuttings: An effective technique for the propagation of Pinus pinaster Ait. New Forests, 41(3), 399412. http://doi.org/10.1007/s11056- 010-9232-x

Mariana, V., Ioan, V., \& Ioana, V. (2011). The substratum influence on cutting's tooting of Cotinus coggygria. Analele Universitatii Din Oradea, XVII, 321324.

Opuku, E.M., Opuni-frimpong, E., \& Adomako, A. (2008). The effects of rooting media on vegetative propagation of two mahogany species (Khaya ivorensis and Khaya grandifoliola), 1 .

Opuni-frimpong, E., Karnosky, D.F., Storer, A.J., Abeney, E.A., \& Cobbinah, J.R. (2008). Relative susceptibility of four species of African mahogany to the shoot borer Hypsipyla robusta (Lepidoptera : Pyralidae) in the moist semideciduous forest of Ghana, 255, 313-319. http://doi.org/10.1016/j.foreco.2007.09 .077

Opuni-Frimpong, E., Karnosky, D.F., Storer, A.J., \& Cobbinah, J.R. (2008). Key roles of leaves, stockplant age, and auxin consentration in vegetative provegation of two African mahagonies: Khaya anthotheca Welw. and Khaya ivorensis A. Chev. New Forests, 3 (6), 115-123. http://doi.org/10.1007/s11056-0089087-6

OuYang, F., Wang, J., \& Li, Y. (2015). Effects of cutting size and exogenous hormone treatment on rooting of shoot cuttings in Norway spruce [Picea abies (L.) Karst.]. New Forests, 46(1), 91105. http://doi.org/10.1007/s11056014-9449-1

Owusu, S.A., Opuni-Frimpong, E., \& Antwi-Boasiako, C. (2014). Improving regeneration of mahogany: Techniques for vegetative propagation of four 
African mahogany species using leafy stem cuttings. New Forests, 45(5), 687-697.

http://doi.org/10.1007/s11056-0149431-y

Rupp, L., \& Wheaton, A. (2014). Nurturing Native Plants: A guide to vegetative propagation of native woody plants in Utah. (L. Rupp \& A. Wheaton, Eds.). Extension, Utah State University.

Sakai, C., Subiakto, A., Nuroniah, H.S., Kamata, N., \& Nakamura, K. (2002). Mass propagation method from the cutting of three dipterocarp species. Journal of Forest Research, 7(2), 7380.

http://doi.org/10.1007/BF02762511
Stuepp, C., Wendling, I., Trueman, S., Koehler, H., \& Zuffellato-Ribas, K. (2017). The Use of Auxin Quantification for Understanding Clonal Tree Propagation. Forests, 8(1), 27. http://doi.org/10.3390/f8010027

Vlad, I., Mariana, V., \& Ioana, V. (2012). The substratum influence on cutting ' $\mathrm{s}$ rooting of Ficus benjamina, 16(2), 221-223.

Zhao, X., Zheng, H., Li, S., Yang, C., Jiang, J., \& Liu, G. (2014). The rooting of poplar cuttings: A review. New Forests, 45(1), 21-34. http://doi.org/10.1007/s11056-0139389-1 